\title{
Isolation and Amino Acid Sequencing by MALDI-TOF-MS/MS of a Novel Antimicrobial Anionic Peptide from the Skin Secretion of Osteocephalus taurinus (Anura, Hylidae)
}

\author{
Túlio O. G. Costa, ${ }^{a, b}$ Richardson A. Almeida, ${ }^{a}$ Jorge T. Melo, ${ }^{c}$ Hector H. F. Koolen, ${ }^{*, d}$ \\ Felipe M. A. da Silva, ${ }^{a}$ José Roberto S. A. Leite, ${ }^{e}$ Maura V. Prates, ${ }^{c}$ \\ Carlos Bloch Jr. ${ }^{c}$ and Angelo C. Pinto ${ }^{b}$
}

${ }^{a}$ Departamento de Química, Universidade Federal do Amazonas, 69077-000 Manaus-AM, Brazil

${ }^{b}$ Instituto de Química-CT, Universidade Federal do Rio de Janeiro, Cidade Universitária, 21945-970 Rio de Janeiro-RJ, Brazil

cEMBRAPA Recursos Genéticos e Biotecnologia, Parque Estação Biológica, 70770-900 Brasília-DF, Brazil.

'Intituto de Química, Universidade Estadual de Campinas, 13084-971 Campinas-SP, Brazil

${ }^{e}$ Núcleo de Pesquisa em Biodiversidade e Biootecnologia, Biotec, Campus de Parnaíba, Universidade Federal do Piauí, 64202-020 Parnaíba-PI, Brazil

\begin{abstract}
Por meio de técnicas cromatográficas, um novo peptídeo aniônico, denominado otacidina, foi isolado das secreções cutâneas de três anuros brasileiros Osteocephalus taurinus. O sequenciamento de novo dos aminoácidos foi realizado por meio de análises por espectrometria de massas por tempo de vôo acoplada à ionização dessortiva de matriz por laser (MALDI-TOF-MS/MS). O potencial antimicrobiano deste novo metabólito foi avaliado contra cepas de Escherichia coli e Pseudomonas aeruginosa, sendo observadas concentrações inibitórias mínimas (MICs) de 37,4 e $78,4 \mathrm{mM}$, respectivamente. Este trabalho é apenas o segundo relato de um peptídeo aniônico com propriedades antimicrobianas, isolado da pele de um anfíbio.
\end{abstract}

By means of chromatographic techniques, a novel anionic peptide, named otacidin, was isolated from the skin secretions of tree Brazilian anurans Osteocephalus taurinus. The de novo sequencing of the amino acids was performed by matrix-assisted laser desorption ionization time-of-flight mass spectrometry (MALDI-TOF-MS/MS) analyses. The antimicrobial potential of this novel metabolite was evaluated against Escherichia coli and Pseudomonas aeruginosa, being observed minimum inhibitory concentration (MICs) of 37.4 and $78.4 \mathrm{mM}$, respectively. This work is just the second report of an antimicrobial anionic peptide from an amphibian.

Keywords: anionic peptide, antimicrobial peptide, Osteocephalus taurinus, skin secretion.

\section{Introduction}

Amphibian skin secretions comprise an alternative source of bioactive molecules which acts as a protection against microorganisms. ${ }^{1}$ These molecules are mainly toxic alkaloids $^{2}$ and antimicrobial peptides (AMP). ${ }^{3}$ Granular glands in the skin of anuran amphibians, particularly those belonging to the families Pipidae, Hylidae, Hyperoliidae, Pseudidae and Ranidae, synthesize and secrete a remarkably

*e-mail: hectorkoolen@gmail.com, hector.koolen@iqm.unicamp.br diverse array of antimicrobial peptides, 10-50 residues in length, that are released onto the outer layer of the skin to provide an effective and fast-acting defense against harmful microorganisms. ${ }^{4}$ Antimicrobial peptides encompass a wide variety of structural motifs. Many peptides have $\alpha$-helical structures. The majority of these peptides are cationic and amphipathic but there are also hydrophobic $\alpha$-helical peptides which possess antimicrobial activity. ${ }^{5}$ Anionic antimicrobial peptides (AAMP) are very rare and their mode of action still is unknown. ${ }^{6}$ Osteocephalus taurinus is an arboreal and nocturnal frog species belonging to the 
Hylidae family, ${ }^{7}$ which is easily found through the Central and North Brazil, where the mainly records are from the Amazon Rain Forest. ${ }^{8}$

In this Communication it is reported the identification of a novel anionic peptide from the skin secretions of the tree frog $O$. taurinus by means of analytical and preparative chromatographic methods, matrix-assisted laser desorption ionization time-of-flight (MALDI-TOF/TOF) mass spectrometry and de novo interpretation of peptide fragmentation spectra. The peptide was also synthesized and tested against several bacteria strains.

\section{Results and Discussion}

The crude skin secretion of $O$. taurinus was fractionated by semi-preparative reversed-phase high-performance liquid chromatography (RP-HPLC) and yielded a number of unresolved fractions that were better investigated after at least an additional separation experiments. The fraction containing the peptide otacidin eluted at $37 \%$ ACN/ $/ .1 \%$ TFA (trifluoroacetic acid), and after purification was submitted to analytical RP-HPLC due to prove its purity. The purified fraction in a MALDI-TOF-MS analysis showed the protonated molecule at $m / z .1706 .05[\mathrm{M}+\mathrm{H}]^{+}$and its sodium cluster at $m / z, 1728.49[\mathrm{M}+\mathrm{Na}]^{+}$. The amino acid sequence of the new peptide named otacidin was confirmed by directly de novo MALDI-TOF-MS/MS sequencing experiments of the protonated molecule ion (Figure 1). The obtained sequence DSVASSAAQELSGVLASN was aligned in Table 1 using CLUSTAL V multiple sequence alignment software. ${ }^{9}$

The precursor sequence alignment of otacidin with other known peptide sequences using FASTA 3 program revealed no similar hits to this peptide confirming its novelty. This new peptide can be fitted into an $\alpha$-helix type of secondary structure using theoretical information predicted by SOPMA program. The isoelectric point (pI) of otacidin was predicted by the ExPASy MW/pI tool program, ${ }^{10}$ which showed a pI of 3.37 .

The new peptide otacidin was then synthesized by the solid phase approach, ${ }^{11}$ and the purified synthetic otacidin was evaluated in vitro for its antibacterial properties. Synthetic otacidin exhibited antibacterial activity against two human pathogenic microbial strains, namely, Escherichia coli and Pseudomonas aeruginosa. The minimum inhibitory concentration (MIC) values determined against these Gram-negative bacteria were 37.4 and $74.8 \mu \mathrm{M}$, respectively (Table 2). For comparison purposes, the MIC value of the commercial drug amoxicillin was determined showing variable specificities and activities (Table 2). The bactericide effect of otacidin was slightly higher against $P$. aeruginosa when compared to the standard drug.

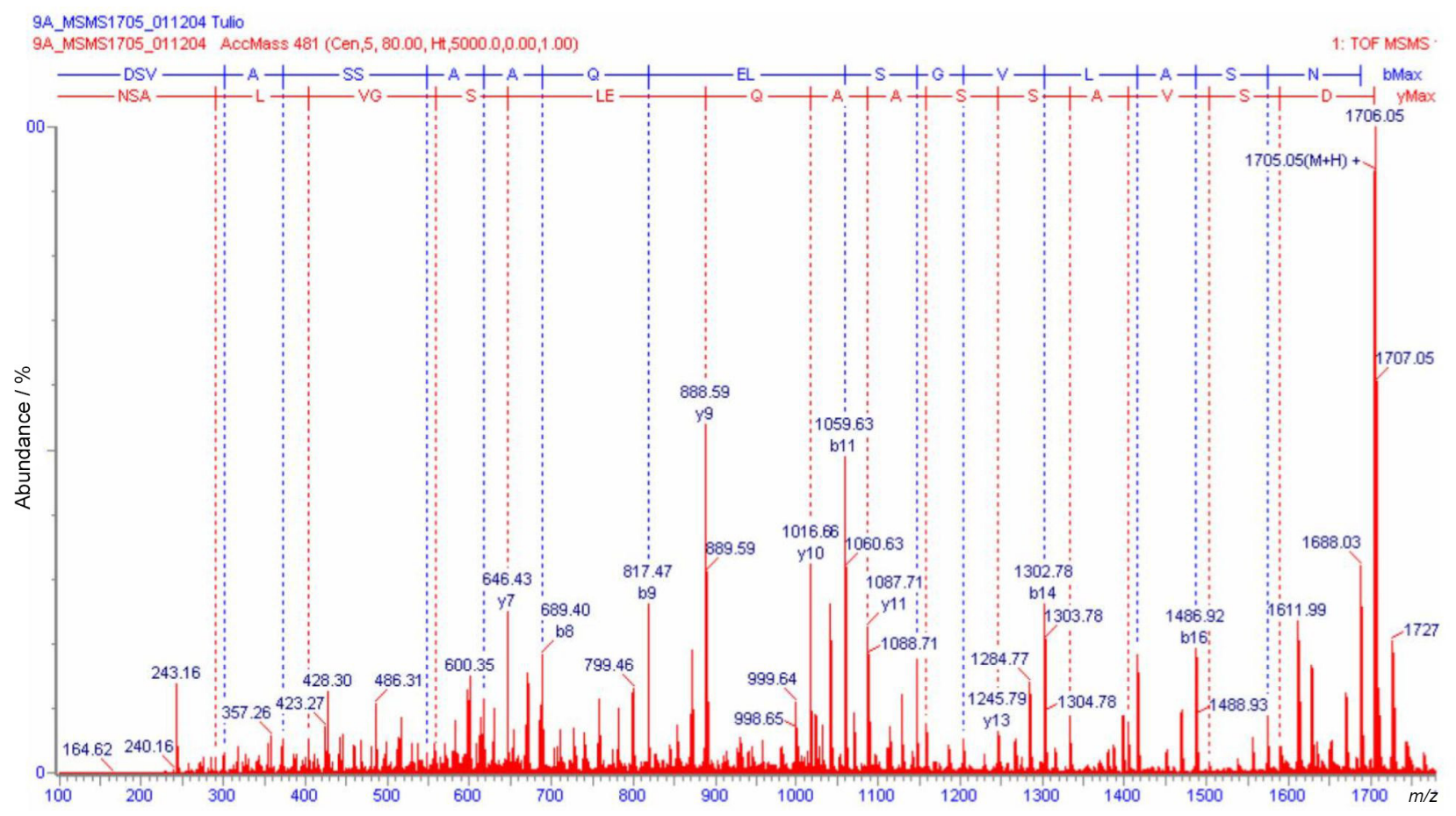

Figure 1. De novo sequencing of the peptide otacidin (O. taurinus) $\mathrm{m} / \mathrm{z} 1706.05[\mathrm{M}+\mathrm{H}]^{+}$. An Applied 4700 Proteomics mass spectrometer was used with $\mathrm{N}_{2}$ as CID gas. The observed fragments allowed complete assignment of the major $\mathrm{y}$ - and $\mathrm{b}$ - ion series. The peptide sequence using one-letter code following the $y$ - and $b$ - series orientation is shown on the top part of the graph. 
Table 1. Predicted fragment ions from otacidin matching the observed ones, within 0.1 Da mass tolerances

\begin{tabular}{|c|c|c|c|c|c|}
\hline $\mathrm{N}^{-T_{e r m}}{ }^{\mathrm{a}}$ & Ion $^{b}$ & $y-$ Series $^{c}$ & b-Series ${ }^{\mathrm{d}}$ & w-b Ions ${ }^{\mathrm{e}}$ & C-Term ${ }^{\mathrm{f}}$ \\
\hline 1 & $\mathrm{D}$ & - & - & & 18 \\
\hline 2 & $\mathrm{~S}$ & 1590.70 & 203.06 & & 17 \\
\hline 3 & $\mathrm{~V}$ & 1503.76 & 302.13 & & 16 \\
\hline 4 & A & 1404.69 & 373.17 & & 15 \\
\hline 5 & $\mathrm{~S}$ & 1333.65 & 460.20 & & 14 \\
\hline 6 & $\mathrm{~S}$ & 1246.62 & 547.23 & & 13 \\
\hline 7 & A & 1159.59 & 618.27 & & 12 \\
\hline 8 & A & 1088.55 & 689.31 & & 11 \\
\hline 9 & Q & 1017.52 & 817.36 & & 10 \\
\hline 10 & $\mathrm{E}$ & 889.46 & 946.41 & & 9 \\
\hline 11 & $\mathrm{~L}$ & 760.42 & 1059.49 & 701.35 & 8 \\
\hline 12 & $\mathrm{~S}$ & 647.33 & 1146.52 & & 7 \\
\hline 13 & $\mathrm{G}$ & 560.30 & 1203.54 & & 6 \\
\hline 14 & V & 503.28 & 1302.61 & & 5 \\
\hline 15 & $\mathrm{~L}$ & 404.21 & 1415.70 & 345.14 & 4 \\
\hline 16 & A & 291.13 & 1486.73 & & 3 \\
\hline 17 & $\mathrm{~S}$ & 220.09 & 1573.77 & & 2 \\
\hline 18 & $\mathrm{~N}$ & 133.06 & - & & 1 \\
\hline
\end{tabular}

a,f $\mathrm{N}$-and C-terminal residue positions in the peptide sequence, respectively; ${ }^{\mathrm{b}}$ refers to the corresponding amino acids; ${ }^{\mathrm{c}, \mathrm{d}}$ report the parent ion fragmentation pattern, following the $y$ - and b-series, respectively; ${ }^{e}$ reports the side-chain fragmentations that allow the discrimination of isobaric amino acids.

Table 2. Antibacterial activity of otacidin and commercial drugs

\begin{tabular}{lcc}
\hline \multirow{2}{*}{ Microbial strain } & \multicolumn{2}{c}{$\mathrm{MIC} / \mu \mathrm{M}$} \\
\cline { 2 - 3 } & Otacidin & Amoxicillin \\
\hline E. coli & 37.4 & 28.0 \\
$P$. aeruginosa & 78.4 & 102.1 \\
\hline
\end{tabular}

Antimicrobial host defense peptides are widely distributed in animals and plants, and are the most ancient host defense factors. Most of these peptides have cationic properties $^{12}$ that allow both electrostatic and hydrophobic interactions with the bacterial cytoplasmic membrane, which usually comprises negatively charged phospholipids. A few anionic antimicrobial peptides were previously isolated from sheep, ${ }^{12}$ human, ${ }^{13}$ crab, ${ }^{6}$ annelids ${ }^{14}$ and only once from a skin secretion of the frog Bombina maxima. ${ }^{5}$ This type of AMP contains hydrophilic and acidic amino acids, which are opposite in charge (pI 2.5 to 3.5), and are considerably smaller $(<1 \mathrm{kDa})$ in size when compared with regular AMP. ${ }^{15}$ The antimicrobial spectrum and action mechanisms are not established for this rare class of antimicrobial peptides. This work reinforces that this class exist naturally as part of the innate defense system of many frog species.

\section{Conclusions}

The present work describes the purification and characterization of a new peptide named otacidin, which constitutes a rare type of peptides and only the second example of anionic antimicrobial peptide from an amphibian skin. It has been speculated that the wide distributions of AMPs with several biological properties is important for the protection of these frogs against invasions of a wide array of different pathogens. ${ }^{16}$ With respect to the development of antibiotics, the current antimicrobial peptide otacidin provides a potential new template.

\section{Experimental}

\section{Amphibians}

Frogs skin secretions were obtained from adult specimens of O. taurinus ( $\mathrm{n}=7$, captured in Manaus City, Amazon State, Brazil). Frogs were collected according to the Brazilian Environmental Protection Agency (IBAMA), under the license number 097/96-DIFAS (Process No. 0637/91A.C).

\section{Peptide purification}

Frog secretions were obtained by mild electric stimulation of the skin granular glands of $O$. taurinus for a few seconds and freshly collected in distilled water. The water-soluble secretions from each species were filtered by gravity through filter paper, frozen and lyophilized. Peptide separation was performed by application ( $5 \mathrm{mg}$ aliquots each time) of the crude extract to a semi-preparative Vydac reverse-phase (RP) chromatographic column, $\mathrm{C}_{18}, 5 \mu \mathrm{m}(218 \mathrm{TP} 510 ; 10 \mathrm{~mm} \times$ $250 \mathrm{~mm}$ ) in HPLC system (Shimadzu Co.) Peptides were purified by using linear gradients, initially $0-65 \%$ acetonitrile containing $0.1 \%$ TFA for $55 \mathrm{~min}$. The experiments were monitored at 216 and $280 \mathrm{~nm}$. Fractions were collected manually and lyophilized. The isolated fractions were submitted to another chromatographic step using a Vydac 218TP54, C18, $5 \mu \mathrm{m}(4.6 \mathrm{~mm} \times 250 \mathrm{~mm})$ analytical column, with optimized gradients of acetonitrile in $0.1 \%$ TFA over $60 \mathrm{~min}$.

\section{Peptide sequencing}

De novo sequencing of the otacidin was performed by MS/MS in a 4700 proteomics analyzer with TOF-TOF optics (Applied Biosystems). The MS and MS/MS spectra were carried out in reflector mode with external calibration, using the 4700 calibration mixture kit (Applied 
Biosystems). Chromatographic fractions were dissolved in an $\alpha$-cyano-4-hydroxycinnamic acid matrix solution (1:1, $\mathrm{v}: \mathrm{v})$, spotted into a MALDI target plate and dried at room temperature for $15 \mathrm{~min}$. Peptide de novo sequencing was performed by precursor ion fragmentation, using $\mathrm{N}_{2}$ as collision-induced dissociation (CID) gas. Peptide sequence alignments and similarity searches were performed using the FASTA 3 program on the ExPASy molecular server. ${ }^{10}$ Secondary structure prediction was performed using SOPMA, also at this server. ${ }^{17}$

\section{Solid phase peptide synthesis}

The peptide was manually synthesized by the solid phase approach using the Fmoc/t-butyl chemistry, ${ }^{11}$ according to the previous employed methodology. ${ }^{18}$

\section{Antimicrobial tests}

Antibacterial activity of otacidin against gram-negative bacteria was determined by the broth microdilution assay. ${ }^{19}$ The microorganisms used were E. coli ATCC 25922 and $P$. aeruginosa ATCC 27853. The $P$. aeruginosa wild tipe (wt) strain was isolated in the Pathology Laboratory from the University Hospital of Brasília (HUB), Brasília City, Brazil. Single colonies of bacteria were inoculated into culture medium (3\% trypticase soy broth) and cultured overnight at $37{ }^{\circ} \mathrm{C}$. An aliquot of this primary culture was transferred to $50 \mathrm{~mL}$ of fresh medium and incubated for additional 3-6 h at $37{ }^{\circ} \mathrm{C}$ in order to obtain the cells in mid-logarithmic phase. The bioassays were performed by liquid growth inhibition assay as described by Bulet et al. ${ }^{20}$ Otacidin was dissolved in sterile Milli-Q water and diluted eight-fold in trypticase soy broth (TSB; Oxoid) broth. The highest concentration used for the assay was $100 \mu \mathrm{mol} \mathrm{L}^{-1}$. The final volume was $250 \mu \mathrm{L}$ ( $25 \mu \mathrm{L}$ of the peptide test in water, $25 \mu \mathrm{L}$ of the inoculums in TSB and $200 \mu \mathrm{L}$ of TSB broth). After incubation for $20 \mathrm{~h}$ at $37^{\circ} \mathrm{C}$, the inhibition of bacterial growth was determined by measuring absorbance at $595 \mathrm{~nm}$. The lowest concentration of peptide that completely inhibited growth of the bacteria was defined as MIC. The MIC values were the average values obtained in triplicates, in three independent measurements and they were compared with MICs obtained for conventional antibiotics.

\section{Acknowledgments}

This work was funded by grants of the Conselho Nacional de Desenvolvimento Científico e Tecnológico (CNPq) and the Coordenação de Aperfeiçoamento de Pessoal de Nível Superior (CAPES).

\section{References}

1. Nizet, V.; Ohtake, T.; Lauth, X.; Trowbrigde, J.; Rudisill, J.; Dorshner, R. A.; Pestonjamasp, V.; Piraino, J.; Huttner, K.; Gallo, R. L.; Nature 2001, 414, 454.

2. Daly, J. W.; Kaneko, T.; Wilham, J.; Garraffo, M.; Spande, T. F.; Espinosa, A.; Donnelly, M. A.; Proc. Natl. Acad. Sci. USA 2002, 99, 13996.

3. Brogden, K. A.; Nature Rev. 2005, 3, 238.

4. Conlon, J. M.; Kolodziejek, J.; Nowotny, N.; Biochim. Biophys. Acta 2004, 1696, 1.

5. Lai, R.; Liu, H.; Lee, W. H.; Zhang, Y.; Biochem. Biophys. Res. Commun. 2002, 295, 796

6. Wang, K. J.; Huang, W. S.; Yang, M.; Chen, H. Y.; Bo, J.; Li, S. J.; Wang, G. Z.; Mol. Immunol. 2007, 44, 1961.

7. Costa, T. O. G.; Morales, R. A. V.; Brito, J. P.; Gordo, M.; Pinto, A. C.; Bloch, C.; Toxicon 2005, 46, 371.

8. Jungfer, K.; Hold, W.; Amphybia-Reptilia 2002, 23, 21.

9. Higgins, D. G.; Sharp, P. M.; Comput. Appl. Biosci. 1989, 5, 151.

10. http://web.expasy.org/compute_pi/accessed in September 2012.

11. Chan, W. C; White, P. D.; Fmoc Solid Phase Peptide Synthesis: A Practical Approach, $3^{\text {th }}$ ed.; Oxford University Press: Oxford, UK, 2000.

12. Brogden, K. A.; de Lucca, A. J.; Bland, J.; Elliot, S.; Proc. Natl. Acad. Sci. USA 1996, 93, 412.

13. Schittek, B.; Hipfel, R.; Sauer, B.; Bauer, J.; Kalbacher, H.; Stevanovic, S.; Schirle, M.; Schroeder, K.; Blin, N.; Meier, F.; Rassner, G.; Garbe, C.; Nat. Immunol. 2001, 2, 1133.

14. Tasiemski, A.; Vandenbulcke, F.; Mitta, G.; Lemoine, J.; Lefebvre, C.; Sautiere, P. E.; Salzet, M.; J. Biol. Chem. 2004, 279, 30973.

15. Nicolas, P.; Mor, A.; Annu. Rev. Microbiol. 1995, 49, 277.

16. Mor, A.; Hani, K.; Nicolas, P.; J. Biol. Chem. 1994, 269, 31635.

17. Garnier, J. Osguthorpe, D.; Robson, B.; J. Mol. Biol. 1978, 120, 97.

18. Leite, J. R. S. A.; Silva, L. P.; Rodrigues, M. I. S.; Prates, M. V.; Brand, G. D.; Lacava, B. M.; Azevedo, R. B.; Bocca, A. L.; Albuquerque, S.; Bloch Jr., C.; Peptides 2005, 26, 565.

19. National Committee for Clinical Laboratory Standards; Performance Standards for Antimicrobial Susceptibility Testing, Approved standard M100-S9, $4^{\text {th }}$ ed. Wayne, PA: NCCLS; USA, 1999.

20. Bulet, P.; Cociancich, S.; Dimarcq, J. L.; Lamber, J.; Hoffmann, D.; Hoffmann, J. A.; J. Biol. Chem. 1991, 236, 24520.

Submitted: July 26, 2012

Published online: January 30, 2013

FAPESP has sponsored the publication of this article. 